\title{
Kuvvetler Ayrılığı İlkesi ve Anayasa Mahkemesinin Yorumu (Karşılaştırmalı Anayasa İncelemesi)
}

\section{Dr. Öğr. Üyesi M. Fatih Çınar ${ }^{1 *}$}

Gelis tarihi: 13.06 .2019

Kabul tarihi: 16.07.2019

\section{Atıf bilgisi:}

IBAD Sosyal Bilimler Dergisi

Sayı: $5 \quad$ Sayfa: $89-100$

Yıl: 2019 Dönem: Güz

This article was checked by Turnitin. Similarity Index 17\%

1 İstinye Üniversitesi, Türkiye, fatih.cinar@istinye.edu.tr,

ORCID ID 0000-0002-1849-7161

\footnotetext{
* Sorumlu yazar
}

\begin{abstract}
ÖZ
Bilinen tarih savaşlar, katliamlar, kölelik uygulamaları, zalim yönetimler yan insanlığın çektiği büyük acılar ile doludur. Modern zamanlara yaklaşıldığında insan hak ve özgürlüklerinin demokrasi idealiyle birlikte yükselmeye başladığı görülmektedir. Egemenliğin dolayısıyla yasama, yürütme ve yargı kuvvetlerinin monarkın elinde tekelci bir şekilde bir daha toplanmaması için yazılı ve fiili hukuki güvencelere bağlanması anayasal demokrasi konseptini ortaya çıkarmıştır. Anayasal demokrasilerde devlet yaklaşımı, yasama, yürütme ve yargı kuvvetlerini ayrıştırır ve kuvvetlerin her birinin diğeri karşısında özerk yapıda olmasını zorunlu kılar. Anayasa tartışmaları Türkiye'de hep var olagelmiştir. Her anayasa değişikliğinde, demokrasi idealinden ve kuvvetler ayrılığı ilkesinden uzaklaşıldığı eleştirileri yükselirken, aynı oranda bu hedeflere yaklaşıldığını savunan görüşlere de rastlanmaktadır. Bu çalışmamızda kuvvetler ayrılığı ilkesi konusundaki görüşlere değinilecek ve günümüzde gelişmiş olarak kabul edilen beş devletin (ABD, Almanya, Fransa, Rusya ve İngiltere'nin) anayasal uygulamalarındaki mevcudiyeti incelenecektir. Kuvvetler ayrıllğı ilkesinin evrensel konum ve değeri ortaya koyulduktan sonra Türkiye Cumhuriyeti Anayasasındaki düzenleniş biçimi ve Anayasa Mahkemesinin yeni tarihli bir kararında kuvvetler ayrıllğı ilkesine ilişkin getirdiği yorum ele alınacaktır. Bu makale ile kuvvetler ayrılığı ilkesinin kapsamı, Türk anayasal sistemi açısından bulunduğu konum karşılaştırmalı olarak bir değerlendirmeye tabi tutulacak ve normatif yönden daha açık bir düzenleme gerekliliğinin sebepleri izaha çalışılacaktır.
\end{abstract}

Anahtar Kelimeler: Kuvvetler Ayrılığı İlkesi, Karşılaştırmalı Anayasa Hukuku, T.C. Anayasa Mahkemesi. 


\title{
Principle of Separation of Powers and the Interpretation of Constitutional Court (Comparative Constitutional Review)
}

\author{
Dr. Lec. M. Fatih Çınar ${ }^{*}$
}

First received: 13.06 .2019 Accepted: 16.07 .2019

\section{Citation:}

IBAD Journal of Social Sciences Issue: 5 Pages: 89-100

Year: 2019 Session: Fall

This article was checked by Turnitin. Similarity Index 17\%

1 Istinye University, Turkey,
fatih.cinar@istinye.edu.tr, ORCID ID 0000-0002-1849-7161

\section{* Corresponding Author}

\begin{abstract}
The known history is full of wars, massacres, slavery, cruel administrations, and human suffering. When modern times are approached, it is seen that human rights and freedoms started to rise together with the ideal of democracy. In order for the sovereignty, therefore, the legislative, executive and judicial forces do not monopolize again in the hands of the monarch, written and actual legal assurances have brought the concept of constitutional democracy. In constitutional democracies, the state approach distinguishes the legislative, executive and judicial powers and forces each of the forces to be autonomous in relation to the other. In Turkey, there are always discussions on the Constitution. In every constitutional amendment criticisms are rising on away from the ideal of democracy and the principle of separation of power, there are while at the same rate the views of advocating that these goals are approached. In this study, the views on the principle of separation of powers will be discussed and the existence of the five states (US, Germany, France, Russia and the UK), which are accepted as advanced today, will be examined. After the explaining the universal position and value of separation of powers, the arrangement of the Constitution of Turkish Republic is in a new decision of the Constitutional Court, the interpretation of the principle of separation of powers will be discussed. With this paper, the scope of the principle of separation of powers and the position of the Turkish constitutional system will be discussed comparatively, and a proposal will be made in the context of a clearer constitutional arrangement requirement.
\end{abstract}

Keywords: The Principle of Separation of Powers, Comparative Constitutional Law, Constitutional Court of Turkish Republic. 


\section{GíRIŞ}

Tarihsel süreç içinde çok çeşitli hükûmet sistemleri ve devlet yönetim modelleri ortaya çıkmıştır. 19. yüzyıla değin, genel olarak uygulanan model, bir monarkın egemenliği ele geçirmesi ve tüm yetkileri keyfi bir şekilde kullanarak devleti yönetmesi şeklinde olmuştur. Bu kontrolsüz yapı, devletin üç temel işlevini oluşturan yasama, yürütme ve yargı kuvvetlerinin monark tarafından sınır tanımaz şekilde kullanılmasına olanak vermiştir. Çoğu zaman da insanların büyük acılar çekmesiyle neticelenen uygulamalar ile karşılaşılmıştır. İnsan hak ve özgürlükleri konseptinin gelişmeye başlamasıyla birlikte yönetimin sınırlandırılması ve ortaya koyduğu haksızlıkların önlenmesi düşüncesi, paralel bir ilerleme göstermiştir. Anılan üç kuvvetin özerk hale getirilmesi suretiyle, birbirini dengeleyerek frenlemesi mekanizması, iktidarın sınırlandırılması düşüncesi için faydalı bir model olarak ortaya çıkmıştır. Buradaki özerklik kavramını, ayrı bir hukuki düzenlemeye bağlı olarak kendi kendini yönetme yetkisi muhtariyet, otonom olma şeklinde tanımlamak mümkündür. Kuvvetler ayrıllı̆ı devlet fonksiyonları arasında hem yatay ve hem de dikey güç dağılımı yapılmak suretiyle gerçekleştirilebilir. Yasama ve yürütme fonksiyonlarının yetki alanları kesin çizgilerle ayrıştırıldığında, yatay bir kuvvetler ayrılığından söz edilebilirken; yasama ve yürütmenin kendi içinde görev ve yetki bölüştürmesi yapılmak suretiyle dikey bir kuvvetler ayrıllğı sağlanabilmektedir. Bunu sağlamanın yolu olarak da devlet fonksiyonlarının farklı siyasi odaklara aktarılması yani kuvvetler ayrılı̆̆ ilkesi (seperation of powers) çeşitli yazarlar tarafından tanımlanmaya ve anayasal demokrasinin bir şartı olarak benimsenmeye başlanmıştır.

İnceleme konusunu oluşturan kuvvetler ayrılığı ilkesinin daha iyi anlaşılabilmesi maksadıyla tarihsel süreçte ilkeyle bağlantılı olan görüş ve düşüncelere değinilerek konuya giriş yapılmıştır. Takiben genel kabul gören tanımı ortaya koyulduktan sonra günümüzde sosyal, ekonomik ve hukuki yönlerden gelişmiş devletler düzeyinde olan ve aynı zamanda uyguladıkları hükümet sistemleri ile modellerinin emsali kabul edilen beş devletin (Başkanlık-ABD, Klasik Yarı Başkanlık-Fransa, Güçlü/Süper Yarı Başkanlı-Rusya, Klasik Parlamentarizm-Almanya ve Monarşik Parlamentarizm-Ingiltere'nin) anayasal uygulamalarında kuvvetler ayrılı̆̆ ilkesinin konum ve değeri ortaya koyulmaya çalışılmıştır. Karşılaştırmalı anayasa hukuku analizi yapılabilmesi maksadıyla Türkiye Cumhuriyeti Anayasasında kuvvetler ayrılığı ilkesinin düzenleniş biçimi sunulmuştur. Anayasa Mahkemesinin yeni tarihli bir kararında kuvvetler ayrıllğı ilkesine ilişkin yorumu ve ilkeye dayanarak verdiği emsal nitelikli bir karar değerlendirilmiştir. Anayasa Mahkemesinin kararından görüleceği üzere anayasada dolaylı bir anlatım olması ve sarih bir düzenleme bulunmamasının getirdiği sakıncalara vurgu yapılarak, anayasada kuvvetler ayrılığı ilkesine açıkça yer verilmesi ve kapsamının/kaplamının belirlenmesinin gerekliliği konusunda öneri getirilmeye çalışılmıştır.

\section{Kuvvetler Ayrılığı İlkesinin Kapsamı}

Kuvvetler ayrılığı gereği devletin her unsuru kendi fonksiyonlarını yerine getirme bakımından özgür olmalıdır. Uygulamada yasama kuvveti sadece yasaları yapmalı yönetsel işlerle yürütme işlerine karışmamalı, yargısal hükümler vermemelidir. Yürütme gücü ise yasaları işletmeli ama yasa çıkartmamalı ya da yasa niteliği taşıyan genel ve soyut kural koyamamalıdır. Yargı gücü ise hukuku olaylara uygulamakla yetinmeli, hukuksal kurallar koyamadığ 1 gibi yürütmenin yerine geçerek idari kararlar da alamamalıdır. Böylece kuvvetler özerkleşirler ve işlevleri sınırlandırılmış olur. Kuvvetlerin özerklikleri sağlanamaz ise birbirlerinden ayrı olma nitelikleri zedelenir ve buna koşut olarak işlevleri zayıflar ve bazıları yok olup gider. Kuvvetler yapılandırılırken olabildiğince birbirinden bağımsız k1lınmaları esastır (Doehring, 2002, s.195). Devlet gücünün, üç ayrı anayasal organ arasında paylaştırılması ve bu organların birbirlerini denetlemesi kuvvetler ayrılığı teorisinin özünü oluşturmaktadır (Aslan, 2010, s.25). Kuvvetlerin bir diğeri ile olan ilişkilerinin matematĭgi, ortaya hükûmet sistemlerini çıkarmaktadır.

\section{Kuvvetler Ayrılığı İlkesinin Tarihsel Altyapısı}

Devletin sınırsız kudretini belli kurallara bağlama düşüncesi modern çağın bir olgusu gibi görünse de aslında devleti yönetenlerin yetkilerinin sınırlandırılması emeli antik çağlardan günümüze değin siyaset felsefesinin önemli bir akıl yürütme alanı olagelmiştir. Devleti yönetenlerinin görev, yetki ve sorumluluklarının sınırlarının belirlenmesine yönelik olarak öne çıkan düşünürler olarak karşımıza, 
Aristoteles (M.Ö. 384-322), John Locke (1632-1704) ve Montesquieu (1689-1755) çıkmaktadır (Akın, 1984, s.217).

Aristoteles Antik Yunan Çağının önemli bir filozofudur. M.Ö. 335 yıllarında yazdığı tahmin edilen "Politika" adlı eserinde devlet sistemi üzerine geliştirdiği görüşlerini ortaya koymuştur. Bir bütünsel yapının anlaşılabilmesi için onun her bir parçasının ele alınıp incelenmesi gerektiğini, bu nedenle en iyi hükûmet sistemini ararken devlet faaliyetlerini ya da fonksiyonlarını ayrı ayrı ele almanın gerektiğini, sav olarak öne sürmektedir Aristoteles kitabında:

"Her devlette ü̧̧ organ, fonksiyon vardır. Bütün sorun bu organların en iyi şekilde düzenlenmesindedir. Bunlar iyi bir şekilde düzenlenirse, devlet hayatı intizamlı bir hale gelir. Devletler arasındaki ilerilik ve gerilik farkı, bu organların iyi bir şekilde düzenlenip düzenlenmemesinden ileri gelir. Organlardan biri kamu işlerini görüşüp, kurallara bağlayan genel meclistir. İkincisi hükûmet heyetidir ki bunun mahiyetini yetkilerini ve iş başına gelmesi şeklini belirlemek düzenlemek ve tanzim etmek gereklidir. Üçüncüsü de hâkimler heyetidir." (Aristoteles, [Çev. Mete Tuncay], 1975, s. 132).

Aristoteles'in uyarı ve öngörüleri, tarihsel süreçte ortaya çıkan devletleri, onun hayalleri doğrultusunda şekillendirememiştir. İktidarı eline geçiren kişiler yasama, yürütme ve yargı güçlerini tekerk olarak kullanma ve mevcut kudretlerini genişletme eğiliminde olmuşlardır. Ne kadar iktidar gücü temin edebilmiş ise o yetkilerini olabildiğince tek başlarına ya da kendi hanedanları, yardımcıları, memurları eliyle kullanmışlardır. Bu aşamada İngiliz tarihçi ve politikacı Sir John Dalberg Acton'un “iktidar yozlaştırır, mutlak iktidar mutlak yozlaştırır” sözü akıllara gelmektedir (Acton, 1887, s.1).

Thomas Hobbes, önemli bir İngiliz siyaset kuramcısıdır. 1651 yılında yayınlanan "Leviathan" isimli kitabında, ideal devlet kuramı üzerinde görüşlerini ortaya koymuştur. Devletin oluşumunda, din ve ahlak kurallarının önemini, bireyler arasında oluşan toplumsal sözleşmeyi ele almış bunun sonucunda devleti doğal bir oluşum olarak betimlemiştir.

"Devletin amacı bireysel güvenliktir. Insanların devletler halinde yaşarken kendilerini tabi kıldıkları kısıtlamanın nihai amacı kendilerini korumak ve böylece daha mutlu bir hayat sürmektir. Kişiler kurgusal bir toplum sözleşmesi ile kendi iradelerini devlete devredince, ölümsüz tanrının altında, ölümlü tanrı Leviathan (devlet) ortaya çıkar, o büyük güç yurtta ve yurt dışında güvenliği sağlayabilir. Bu hayatta hem din hem de devletin, dünyevi yönetimden başka bir yönetimi yoktur. Bu nedende bütün egemenlikler tek elde toplanmak zorundadır." (Hobbes, [Çev. Semih Lim], 2007, s.127).

Hobbes'un devlet tasavvuruna göre egemenliklerin tek elde toplanması ve bölünmemesi gerekir. $\mathrm{Bu}$ görüşlerinin devletin fonksiyonlarının birbirinden ayrılmasını öngören kuvvetlerin ayrıllı̆ı kuramı uyumlu olduğu söylenemez ancak dönemin güçlü monarklarının karşısına geçerek söylediği sözlerinin çağının ilerisinde olduğunu gözden kaçırmamak gerekmektedir. İlahi iktidarı kabul etmekle birlikte egemenliği dünyevi iktidar odaklarına tevdi etmesi ve ortaya koyduğu devlet, uyruk, toplum sözleşmesi kuramları, kendisinden sonra bu konularda çalışmalar yapacak düşünürlere yol izi bırakmıştır. Özellikle J.Locke, iktidara çeşitli sınırlar çizilmesi konusunda öne sürdüğü görüşler ile dikkat çekmiştir.

John Locke, İngiltere'de 17'nci yüzyılda tabii hukuk doktrininin bir temsilcisi olarak kuvvetler ayrıllğ 1 konusunda önemli fikirler öne sürmüştür. "Yönetim Üzerine Íki Inceleme" adlı eserinde devlet yönetiminde başlıca üç kuvvetin bulunduğunu ifade etmiştir. Bunları, yasama, yürütme ve konfederatif kuvvetler olarak tasnif eder. Locke'ye göre devlet yetkilerinin kötüye kullanılmasını önlemenin yolu yasama ve yürütme kuvvetlerinin birbirinden ayrılmasından geçer. Çünkü yasama kuvvetini elinde bulunduranlar kanunları kendilerine uygulamama veya onları şahsi çıkarlarını gerçekleştirmek için kullanma eğilimi gösterebilirler. Bu nedenle yasamanın yaptığı kanunları uygulama yetkisinin ayrı bir kuvvete yani yürütmeye ait olması gerekir. Locke, yasama ve yürütme yetkilerini elinde tutan zamanının monarşi kurumuna karşı duruş göstermiştir. Locke, sınırsız ve üstün kabul edilen yasama kudretinin aslında sınırsız olmadığını söyleyen ilk düşünürler arasındadır. 
"Yasalar yapılırken kişilerin can ve mal güvenlikleri ile özgürlüklerin korunması konularında yasa koyucu dilediği gibi davranamaz. Kişilerin mal varlıkları, sahip oldukları maddi veya manevi değerleri kutsaldır. Bu nedenle keyfi olarak dokunulamaz. Yasalar genel nitelikte ve herkes tarafindan kolayca anlaşılabilir olmalıdır. Yasama yetkisi devredilemez." (Locke, [Çev. Serdar Taşçı, Hale Akman], 2002, s.15).

Konfederatif yetki olarak ise Locke, savaş ve barışa karar verme, diğer devletler ile ilişkiler kurma antlaşmalar yapma yetkisini işaret etmektedir. Locke yürütme kuvvetinin ve konfederatif yetkinin yasama gücünün denetimine tabi olması gerektiğini belirtmektedir. O’na göre en üstün kuvvet yasama gücü olup diğer iktidarlar kaynağını ondan almaktadır. Yürütme kuvvetini kullananlar yasamaya karşı sorumluluk taşımaktadırlar. Konfederatif yetki ise yürütme ve yasama güçlerinin emrinde ve onların denetiminde, onlara tabi olarak görev yapmak zorundadır (Göze, 1993, s.156, 150).

Tarihsel süreçte tekâmül eden bu görüşleri derli toplu bir hipotez altında birleştiren ve modern çağın anayasal ilkesi haline getiren Montesquieu'dür. Yazar, ilk pozitivistlerden ve siyaset biliminin kurucularından ayrıca aydınlanmanın ve sosyoloji kuramının öncülerinden kabul edilmektedir.

1689-1755 yılları arasında yaşayan Montesquieu, 1731-1748 yılları arasında 17 yıl boyunca hiç ara vermeden, Brede Şatosunda Kanunların Ruhu Üzerine (De L'esprit des Lois) adlı eseri üzerinde çalışmıştır. İngiltere'nin Anayasası başlıklı bölümde kuvvetler ayrılığına ilişkin görüşlerini açıklamıştır. Politik öğretisi dengeye, iktidarın iktidar ile sınırlandırılması ilkesine dayanmaktadır. Yönetimde bulunan iktidarın devlet gücünü kendi çıkarları istikametinde kullanmasını engellemenin tek yolunun iktidarın bir diğer iktidar ile sınırlandırılması olduğunu öne sürmektedir. Bunu temin için devleti ortaya çıkaran çeşitli kuvvetler birbirinden ayrılmalı, farklı iktidar odaklarına verilmelidir. Siyasal özgürlüğün ve güvenliğin sağlanması iktidarlar dengesi ile kurulabilir, başka türlü kurulamaz. Yazar, bir devlette yasama, yürütme ve yargı fonksiyonları olmak üzere üç temel işlev bulunduğunu ve bunları kullananların iktidar odağı olduklarını kabul etmektedir. Yasama kuvveti devletin genel iradesini temsil etmektedir. Yasama kuvveti geniş anlamıyla kanunlar yapar, değiştirir veya kaldırır. Genel idari fonksiyonun yerine getirilmesi yürütme kuvvetinin işlevidir. Yürütme kuvveti bu işlevini yerine getirerek, yabancı devletlere elçiler göndermek, savaş ve barışa karar vermek gibi uluslararası fonksiyonlar icra ederken, iç barışı sağlamak, kamu düzenini temin etmek gibi başkaca görevler de yerine getirir. Devletin üçüncü işlevi ise mahkemeler tarafından yerine getirilen yargıdır. Yasama organı kendiliğinden toplanıp dağılamaz. Yasamayı toplantıya çağırma yetkisi yürütme kuvvetine ait olmak zorundadır. Ancak yürütme bu yetkisini kötüye kullanarak yasamayı uzun süre toplantıya çağırmaz ve yasamanın yetkilerini kullanmaya başlarsa mutlak iktidar haline gelmiş olur. Bu sebeple yürütme yasamayı her sene toplantıya çağırmak zorundadır. Ancak yasamanın sürekli toplantı halinde olması yarar sağlamaz. Çünkü bu durumda temsilciler ağır bir külfet altında olacakları için hem yürütme hem de yasama, fonksiyonlarını verimli şekilde yerine getiremeyeceklerdir. Yürütmenin yasamanın işlemlerini durdurma yani veto hakkı vardır, aksi takdirde yasama zorbalığa ve tüm yetkileri kendi uhdesinde toplama eğilimine kayabilir. Buna mukabil yasamanın yürütmeyi durdurma yetkisi bulunmamalı, sadece yasaların nasıl uygulanacağını denetleme hakkı tanınmalıdır. Yargı gücü kesinlikle yasama ve yürütmeden ayrılmalıdır. Bu sayede özgürlükler güvence altına alınmış olur. Hâkimin aynı zamanda kanun koyucu olduğu durumlarda, yarg1 gücü yasama gücü ile birleşirse yurttaşların yaşam ve özgürlükleri keyfi bir denetim sürecine bırakılmış olacaktır. Buna benzer bir şekilde yargı kuvvetinin yürütme kuvvetiyle birleşmesi durumunda hâkimlerin şiddet ve baskıya başvurma durumları ortaya çıkabilir. Montesquieu'ye göre üç iktidar tek elde toplanırsa, (bu ister bir kişi ister soylular, isterse halk olsun) her şey bitmiştir

"Yasama iktidarı, yapacağı baskl yasaların yine kendisi baskl yaparak uygularsa o yerde özgürlük kalmaz. Yargı yasamayla birleşmişse, kişinin ne canı ne de özgürlüğü güvencede olmaz, çünkü yargıç aynı zamanda yasa koyucudur ve keyfince karar verebilir. Yargıç yürütme iktidarına da sahipse, yargıç bir zorba olur” (Montesquieu, [Çev. Fehmi Baldaş], 1963, s.293).

İnsan hak ve özgürlükleri, hukuk devleti, anayasal demokrasi gibi ideallerin gereksinimlerinden, tarihsel deneyimlerin süzgecinden geçerek ve gerekliliği doğrulanarak gelen kuvvetler ayrıllğı ilkesi günümüzde çağdaş anayasalara yön veren bir perspektif halini almıştır. 


\section{Çağdaş Anlamıyla Kuvvetler Ayrılığı İlkesi}

Kuvvetler ayrıllı̆̆ teorisinin temelinde, iktidarın mutlak bir hale dönüşmesi ve tekelleşmesi sebebiyle meydana gelen olumsuzlukların ortadan kaldırılması fikri yatmaktadır. Siyası iktidarı kullananlar, kamusal gücü tekelci bir şekilde ele geçirdiklerinde, baskıcı bir yönetim kurmaktaydılar. Bu nedenle yürütmenin sınırlandırılması gerekliliği açıkça ortaya çıkıyordu. Sınırlandırılma için ilk akla gelen pratik çözüm, yasama organına bazı yetkilerin aktarılması olarak görüldü. 1215 tarihli Magna Carta Libertatum ile başlayan ve Kraliyet Konseyi (Privy Council), Kamaralar, Parlamentolar, Meclisler ile günümüze değin uzan süreç ilk anayasacılık hareketlerine, temel olarak gösterilmektedir (Oder, 2004, s.29). Bunun sonucunda yasama organı bir kuvvet olarak belirdi. Yasama kuvvetinin var olmasının, yürütme kuvvetini sınırlandırmaya yeterli olacağ 1 varsayılmaktaydı. Ancak gelişmeler tam da bu şekilde olmadı. Yasamanın artan iş yükü, teknik uzmanlık gerektiren çalışma sahası, yürütmenin kendi nüfuz alanını muhafaza etme yönündeki sabit tutumu, yasamanın giderek pasifize olması ve yürütmenin tekrar geniş bir etki alanına sahip olması sonucunu doğurdu. Bu durum yasamanın yanında yargının da ayrı bir kuvvet olarak güçlendirilmesi düşüncesine zemin hazırladı.

Yürütmenin, yasaların uygulanması, idari işlemler gerçekleştirilmesi, kamusal tasarruflar yapılması, hükûmetin ve kamu idaresinin yönetilmesi, iç ve dış politikanın belirlenmesi, ulusal savunma için gerekli hazırlıkların yapılması şeklindeki geniş görev ve yetkileri her alanda denetim mekanizmalarının geliştirilmesini gerekli kılmaktaydı (Çubukçu, 2015, s.9). Diğer taraftan yasama organının hukuk oluştururken çıkaracağı mevzuatın ve kanunların genel, soyut ve kamu yararını gerçekleştirmeye yönelik içeriğe sahip olması beklenir. Oysa gerçekler ile idealler örtüşmemektedir. Kanunların yapılması sürecinde birçok dış unsurun etkisi altında, hiç de demokrasiye, hukuka, insan hak ve özgürlüklerine ya da kamu yararına uygun olmayan hukuk kuralları çıarılabilmektedir. İşte böyle durumlar için yargı kuvvetinin yasamanın çıkardığı hukuk kurallarının anayasaya uygunluğunu inceleme ve gerekli görürse iptal etmek suretiyle denetleme, görev ve yetkisi ile donatılmas1 gerekmektedir.

Mutlak iktidarın sınırlandırılmasına yönelik geliştirilen teoriler, Montesquieu'ye kadar yargı yetkisini ayrı bir kuvvet alanı olarak görmemiştir. Genel yaklaşıma göre yargı yetkisi, yasaların uygulanmasını denetleyen, hukukun ne olduğunu söyleyen yürütme içinde bir organ olarak kabul edilmiştir. Ancak anayasal demokrasi anlayışının bir gereği olarak yürütmenin gücünün sınırlandırılması gerekliliği, yasamanın sınırlandırma fonksiyonunu yeteri kadar etkin olarak yerine getirememesi, yargı kuvvetini bir güç paylaşımı odağı olarak yükseltmiştir.

Kuvvetler ayrılığı ilkesini ve anayasal demokrasiyi benimsemiş olan devletlerde zamanla yargı kuvvetinin önemi giderek artmıştır. Bunun başlıca sebepleri olarak, yürütmenin birey karşısındaki aşırı güçlü ve karşıt konumda olması, yasamanın ise bireyin ulaşamayacağı kadar uzak bir noktada bulunması gösterilebilir. Ayrıca yürütme ve yasamanın her zaman siyasetin bir tarafinda bulunuyor olmaları da eklenebilir. Hak arayan, hukuki uyuşmazlıklarına çözüm bekleyen, adalet uman birey yönünden ve toplum nazarında yargının önemi ve değeri tarihsel süreç içinde daha da artmıştır.

Günümüzde yargının artan önemi nedeniyle kuvvetler ayrılığının tam olarak uygulanmadığı devletlerde dahi yargının diğer erklerden ayrıştırılması, büyük ölçüde uygulanmaktadır. Yani yargı organının ve yargılama işlevinin bağımsız ve tarafsız olması bu devletlerde dahi kabul edilmektedir (Wheare, 1985, s.36). Modern devletlerin anayasal örgütlenme ve uygulamaları, güçlerin kontrolü ve dengelenmesini sağlayacak şekilde kurgulanmıştır. Bu yönüyle örnek teşkil edebilecek devletlerin anayasalarındaki düzenlemeler dikkat çekicidir.

Fransa, 1958 yılından itibaren Beşinci Cumhuriyet dönemi girmiştir (Fransa'nın Politik Tarihi, www.france-politique.fr). Uygulamakta olduğu Anayasası'nın mütemmim cüzü olan, Fransız İnsan ve Yurttaş Hakları Bildirgesinde kuvvetler ayrılı̆̆ ilkesi vurgulanmış ve açıklıkla düzenlenmiştir: "Hakların güven altına alınmadı̆̆ kuvvetler ayrılığının yapılmadı̆̆ bir toplumda Anayasa yoktur." (İnsan ve Yurttaş Hakları Bildirgesi, avalon.law.yale.edu/18th_century/rightsof.asp).

Fransa üniter devlet yapılanmasına sahiptir. Hükümet modeli olarak yarı başkanlık hükümet sistemini uygulamaktadır. $\mathrm{Bu}$ yönetim sisteminde yürütme organı devlet başkanı, başbakan ve bakanlar kurulundan oluşmaktadır. Fransız Anayasasında kabinenin yapısı, hangi bakanlıkların bulunacağına 
ilişkin bir düzenleme yer almamaktadır. Bu nedenle her başbakan kabinesini kurarken köklü değişiklikler yapabilmektedir. Bu ve benzer düzenlemelerin yürütmeyi güçlendirdiği açıktır. Genel olarak devlet sisteminde yürütmenin bir üstünlüğ̈̈ bulunduğu yönünde bir intiba da oluşmaktadır. Buna karşın, yürütme erkinin hem devlet başkanı hem de başbakan ve onun kabinesi arasında dikey bir kuvvetler ayrılığı ile paylaşıldığı anlaşılmaktadır. Diğer taraftan yargı bağımsızlığına ilişkin hukuki düzenlemeler ve geleneksel eğilim ile yasama organının çift meclisten oluşması, kuvvetler ayrıllı̆ının uygulamada gerçekleştirilmesine dönük tedbirler olarak karşımıza çıkmaktadır (Eroğul, 2016, s.194).

Federal Almanya, 1949'da kabul edilen Anayasayı (Basic Law) uygulamaktadır (Almanya Anayasas1, btg-bestellservice.de/pdf/80201000.pdf). Buna göre yasama yetkisi ve yürütme yetkisi Federal Devlet ile Federe Devletler arasında bölüştürülmüştür. Federe Devletler, sınırlı yetkilerle donanmış da olsa yasama, yürütme ve yargı organlarına sahiptir. Bu yapılanma temelde bir kuvvetler ayrılığı doğurmaktadır. Anayasa'nın 20'inci maddesi: “Yasama anayasal düzene, yürütme ve yargl organları ise yasa ve hukuka bağlıdırlar" şeklinde kuvvetler açıkça sayılmış ve ayrıştırılmıştır.

Almanya, federatif bir devlet yapılanmasına sahip olup hükümet modeli olarak klasik parlamenter hükümet sistemini uygulamaktadır. Bu sistemin temel özelliği, devlet başkanının yetkilerinin, yarı başkanlık ve başkanlık hükümet sistemlerine nazaran daha sınırlı olmasıdır. Buna karşın, devletin işleyişi konusunda, denetim, gözetim ve koordinasyon yetkileri ile donatılmıştır. $\mathrm{Bu}$ devlet fonksiyonları üstü konumlanma, kuvvetler ayrılığında pozitif bir etki yaratmaktadır. Yürütme erkinin etkin öğesini başbakan ve onun kabinesi oluşturmaktadır. Almanya'nın demokratik siyasi tarihinde tek partinin iktidarından çok koalisyon hükümetlerinin fazlalığı göze çarpmaktadır. Bu geleneksel eğilim yürütme içinde doğal olarak güçler paylaşımı yaratmaktadır. Sayılanlarla birlikte, yasama organının çift meclisten oluşması dikey boyutta kuvvetler ayrılığını gerçekleştiren bir teşkilatlanma formudur. Yine yasama organının, yürütme organını gensoru gibi denetim yöntemleriyle denetleyebiliyor olması, hükümeti düşürme yetkisinin bulunması, yargı bağımsızlığına ilişkin anayasal düzenlemeler, hukuki ve fiili kuvvetler ayrılığı uygulamalarını sağlayan olgulardır (Eroğul, 2016, s.254).

Amerika Birleşik Devletleri, başkanlık sistemini uygulamaktadır. Bu sistemde yürütme, parlamenter sistemden ve yarı başkanlık sisteminden farklı olarak tek başlıdır. Parlamenter ve yarı başkanlık sisteminde karşımıza çıkan başbakan ve onun bakanlar kurulu bu modelde bulunmamaktadır. Başkan tek başına hem devletin başı hem de yürütmenin tek egemen kudretidir. Başkan yürütme gücünün tek başına etkin gücünü oluşturmaktadır. Anayasa, başkana siyaseten sorumluluk yüklerken yetki ve sorumluluğun eş dengede tutulabilmesi ve bahse konu ağır sorumluluklarını yerine getirebilmesi için yürütme üzerinde mutlak bir yetkilendirme yoluna da gitmiştir. Başkanın bu güçlü konumu nedeniyle, sistemin kuvvetler ayrılığına uyumlu olmadığı düşünülebilir. Ancak, ABD başkanlık sisteminin kuvvetler ayrılığının en güçlü uygulandığı sistem olduğu konusunda genel bir mutabakat bulunmaktadır. Buna sert kuvvetler ayrılığı adlandırması yapıldığı görülmektedir (Gözler, 2018, s.230).

Anayasası'nın temel parçası olan "Bill of Rights" ve bizzat Anayasa'nın devlet teşkilatını yapılandırdığı kurgu baştan aşağı kuvvetler ayrılığı üzerine şekillenmiştir (ABD Anayasası, archives.gov/founding-docs/constitution-transcript). Eyaletlerin yasama, yürütme ve yargıya ilişkin yetkilerinin bulunması kuvvetler ayrılığına zemin hazırlamaktadır. Yürütme ve yasama organının birbirinden bağımsız göreve gelmeleri ve değişmeleri, birbirini feshedememeleri, federal düzeyde özerk alanlar oluşturmaktadır. Yasama organın çift meclisten oluşması kuvvetler ayrılığının önemli bir görünüm şeklini oluşturmaktadır. Yarg1 gücü ise ABD örneğinde oldukça ayrıcalıklı bir konuma sahiptir. Marbury vs. Madison Davası (1803) ile Anayasa'ya uygunluk denetimi yapma yetkisine sahip olduğu yönünde içtihat ortaya koyan Yüce Mahkeme (Supreme Court) dünyada ilk defa yasaların anayasalara uygunluğunun denetiminin yolunu açmıştır (ABD Yüce Mahkemesi, supremecourt.gov/orders/scannedjournals.aspx). ABD'nin kuvvetler ayrillğı bağlamında güçlü bir emsal oluşturduğu çok açıktır.

İngiltere, klasik anlamda bir anayasa edinmemiştir. Bunun yerine bazı normatif düzenleme içeren belgeleri anayasal belgeler olarak kabul etmiştir. Lordlar Kamarası ile Avam Kamarasının birlikte oluşturdukları "ortak komite" tarafından 2004 yılında İngiliz Anayasal Temel Metinleri tespit edilmiştir. 21 adet belgenin toplamının İngiliz Anayasası'nı oluşturduğu kabul edilmiştir (Birleşik 
Krallık Anayasa Ortak Komitesi, [Joint Committee on Draft Civil Contingencies Bill] publications.parliament.uk/pa/jt200203/jtselect/jtdcc/184/18407.htm). İngiltere tarihte parlamenter demokrasinin doğduğu ve geliştiği bir devlet olarak kabul edilmektedir. Kraliyetin gittikçe sembolik seviyeye gerileyen yetkileri, karşısında başbakanlık kurumunun ve onun kabinesinin güçlendiğini gözlemlemek mümkündür. Ayrıca parlamentonun yürütme üzerindeki denetim gücü ve tarihsel süreçte gelişen etkinliği, modern çağlarda da artarak devam etmiş̧ir.

Büyük Britanya, İngiltere, İskoçya ve Galler'den oluşan 3 ülkeli ada devletini ifade etmektedir. Birleşik Krallık: Büyük Britanya (İngiltere, İskoçya, Galler) ve Kuzey İrlanda olmak üzere 4 ülkeden oluşan bir devleti belirtmektedir (Bilgin, 2015, s.196). Bu devlet grupları arasında çeşitli yasama, yürütme ve yargısal, güç paylaşımları gerçekleştirilmiştir. Ayrıca yürütme fonksiyonu kraliyet, başbakanlık, bakanlar kurulu arasında dikey güç dağılımı ile dağıtılmıştır. Yasama gücünün yürütme organı üzerindeki gensoru, soru ve benzeri parlamenter denetim yetkileri, yarg1 gücünün geleneksel etkinliği ve saygınlığı yapılanmayı fonksiyonel dengeyi temellendirmektedir. Birleşik Krallığın devlet yapılanması ve demokratik geleneksel kültür, kuvvetler ayrılığının temellerini oluşturmaktadır.

Rusya Federasyonu, Anayasası'na göre devlet 80'in üzerinde yönetsel özerkliği/bağımsızlığı bulunan ülke parçalarından oluşmaktadır. Kuvvetler Ayrılığı İlkesi ilk kez 1990 yılında kabul edilen Devlet Egemenliği Bildirisinde yer almıştır. 1992 Anayasa değişikliği ile kuvvetler ayrılığı kuramı Anayasa hükmü olarak düzenlenmiştir (Rusya Federasyonu Anayasas1, ksrf.ru/en/Info/LegalBases/ConstitutionRF/Pages/default.aspx). Anayasa'nın 10'uncu maddesi “Rusya Federasyonu'ndaki devlet iktidarl yasama, yürütme ve yarglya bölünme temelinde uygulanmaktadır. Yasama, yürütme ve yargı organları bağımsızdır”, düzenlemesi ile kuvvetler ayrıllğı ilkesini temel değer olarak kabul etmektedir. Hatta Rusya Anayasasının 16'nc1 maddesi, "Kuvvetler Ayrıllı̆ Illkesini" değiştirilemez maddeler arasına almıştır.

Rusya Federasyonu yarı başkanlık sistemini benimsemiştir. Ancak yarı başkanlık sisteminin klasik modelinde olduğundan tamamen farklı bir şekilde devlet başkanına tevdi edilen geniş yetkiler ile oldukça istisnai bir konuma taşımıştır. Kısa süreli uygulamasında, güçlü liderlerin devlet sisteminde ön plana çıktığı gözlemlenmektedir. Rusya'nın uzun tarihsel geçmişi bir yana bırakı1ır ve yeni Anayasası esas alınırsa genç bir devlet sayılabilir. Anayasası yeni bir ruh ve anlayış ile hazırlanmış olup kuvvetler ayrılığı, demokratikleşme, hukukun üstünlüğü, insan haklarına sayg1 gibi modern demokratik kavramları barındırmaktadır.

Yukarıda ana hatlarıyla, kuvvetler ayrılığı yönünden incelenen beş devletin en dikkat çeken ortak özelliği, parlamentolarının çift meclisli olarak yapılandırılmış olmasıdır. Bir yasa tasarısının parlamentonun bir kanadında kabul edilmesi sonrasında diğer kanadında da incelenmesi, görüşülmesi ve kabul edilmesi gereklidir. Böylece çift meclisli parlamento uygulamasının yasama organı içinde ikinci bir denetim sistemini oluşturmakta ve güçlü bir kuvvetler ayrıllğı statüsü tesis etmektedir.

\section{Kuvvetler Ayrılığı İlkesinin Türk Anayasa Hukukundaki Değeri}

21. yüzyıl ile başlayan süreç Türkiye'de hep var olan Anayasa tartışmalarına daha da hız verdi. 1982 Anayasası'nın kabulünden sonra 20 yılda 8 dar kapsamlı değişiklik yapılmış olmasına karşın, 2003 yılından sonra Cumhurbaşkanının halk tarafından seçilmesi, Başbakanlık kurumunun kaldırılması başta olmak üzere 13 yılda 13 geniş kapsamlı değişikliğin yapıldığına tanık olmaktayız. 2017 yılı başlarında yapılan referandum ile "Cumhurbaşkanlığı Hükûmet Sistemi" olarak adlandırılan yürütmeyi güçlendiren tamamen yeni bir sisteme geçildiğini görmekteyiz. Devlet yapılanması değişirken, kuvvetler ayrılığı ilkesinin de yürütmeyi üstün kılan değiş̧iklikler sebebiyle negatif olarak etkilendiğini söylemek gerekir (Türkiye Cumhuriyeti Anayasası, anayasa.gov.tr/tr/mevzuat/anayasa).

Egemenliğin kaynağının millet iradesi olması nedeniyle tek olduğunu, bu nedenle bölünmesinin ve kuvvetler arasında ayrıştırma yapılmasının aslında mümkün olamayacağını, öne süren görüşler bulunmaktadır. Bu bakış açısı, kamu gücünü kullanan organların bu yetkiyi doğrudan doğruya halktan aldıkları için halk iradesinin bu organlara yansıdığını dolayısıyla devletin belli işlevleri yerine getiren organlarından söz edilmesi gerektiğini savunmaktadır (Doehring, 2002, s.192). Anayasanın başlangıç bölümünü bakıldığında, anılan görüşten ilham alındığını söylemek mümkün olabilir. Ancak kuvvetler ayrılığı ilkesinin görevler ayrımından daha kapsamlı bir yapılanmayı ve uygulamayı gerektirdiğine 
şüphe bulunmamaktadır. Yukarıda ele alınan modern devletlerde, kuvvetler ayrılığının hayata geçirilmesine yönelik olarak oluşturulan teşekküller ve şümullü tatbikatları, ilkenin geniş perspektifini doğrulamaktadır. Aşağıda görüleceği gibi Anayasa Mahkemesi de ilkeyi evrensel olarak uygulanan ve kabul edilen anlamiyla benimsemektedir.

Çalışmanın temel perspektifini oluşturan "Kuvvetler Ayrıllğ İlkesi” çağdaş devlet yapılanmalarının ve demokratik anayasaların temel bir değeri olup demokratik yönden gelişmiş devletlerde tartışma konusu olma vasfını büyük ölçüde yitirmiştir. İncelenen anayasalarda çeşitli biçimlerde yer verildiği anlaşılmaktadır. Türk Anayasa incelemelerinde, kuvvetler ayrılığına ilişkin değerlendirme yapılırken, 1924 Anayasası için "kuvvetler birliği-görevler ayrıllı̆ı" sistemi olduğu; 1961 Anayasası için "kuvvetler ayrılığının gerçekleştirildiği" bir anayasa olduğu ileri sürülmektedir. Özellikle 1961 Anayasası'nın 5, 6 ve 7'nci maddelerinde sirayla yasama yetkisinin, yürütme görevinin ve yargı yetkisinin ayrıştırılarak kayıt altına alınmış olması, çift meclis sisteminin benimsenmesi, Anayasa Mahkemesinin kurulmuş olması kuvvetler ayrılığının gerçekleştirilmesine dönük düzenlemeler olarak gösterilmektedir (Çınar, 2017, s.599). Kuvvetler ayrılığını sağlamak için hem devlet yapılanmasının hem de normatif düzenlemelerin birbiriyle örtüşmesi gerekmektedir. Devlet organlarının görev ve yetki dağılımları kuvvetler ayrılığına uygun olarak yapılandırılırken, anayasa yargısının bulunduğu bir sistem olduğu dikkate alınarak, normatif düzenlemelerin yani lafzi (sözel) düzenlemelerin kuvvetler ayrılığının kapsam ve kaplamını açık bir şekilde betimlemesi gereklidir.

1982 Anayasası, sistemde meydana gelen tıkanıklıkları gidermek ve yürütmeyi güçlendirmek üzerine kurulu bir anlayışla hazırlanmıştır. $\mathrm{Bu}$ yaklaşım anayasa hukukunda "rasyonelleştirilmiş parlamentarizm" olarak adlandırılmaktadır. Geçmiş dönemin olumsuzluklarını giderebilmek adına yapılan, Cumhurbaşkanını yürütme içinde dominant konuma yükseltmek, yine yürütmeyi yasama ve yarg1 üzerinde operasyonel yetkiler ile donatmak, çift meclis sisteminden vazgeçip tek meclisli parlamento sistemine dönmek, Anayasa Mahkemesine başvurma olanaklarını sınırlandırmak gibi kuvvetler ayrılığı ilkesini zayıflatan bir yapılanmaya gidildiği görülmektedir. Buna mukabil, anayasa metninde, kuvvetler ayrılığı prensibine dolaylı da olsa yer verilmiştir. Başlangıç Bölümünde:

"Kuvvetler ayrımının, Devlet organları arasında üstünlük sıralaması anlamına gelmeyip, belli Devlet yetki ve görevlerinin kullanılmasından ibaret ve bununla sinırlı medenî bir işbölümü ve işbirliği olduğu ve üstünlüğ̈̈n ancak Anayasa ve kanunlarda bulunduğu”

kayıtlıdır.

Demokratik devletlerde Anayasa Mahkemelerinin özel bir konumu bulunmaktadır. Birey temel hak ve özgürlükleri ile demokratik devlet yapılanmalarını muhafaza etmenin nihai bir denetim noktasını bu mahkemeler oluşturmaktadır. Anayasa Mahkemeleri, kuvvetler ayrılığının bir gerekliliği olarak hukuken ve fiilen yetkilendirilmiş olmaları halinde anılan denetim fonksiyonunu gerçekleştirebilirler. Demokratik devletlerin temel değeri olan kuvvetler ayrılığı ilkesi her türlü normatif düzenlemede dikkate alınması gereken bir öneme sahiptir. Örneğin, yargı gücünün bağımsız ve tarafsız olmasını zedeleyebilecek bir yasal düzenleme kuvvetler ayrılığını zedeleyeceği için Anayasa Mahkemesi tarafından iptal edilebilmeli ya da yürütmenin yetki alanını aşarak yasamanın kural koyma işlevini gasp eden bir düzenleyici işlem yine kuvvetler ayrılığına aykırılık oluşturduğu gerekçesiyle normatif yönden denetlenebilmeli ve ortadan kaldırılabilmelidir.

1982 Anayasası'nın Başlangıç bölümünde kayıt altına alındığg şekliyle, kuvvetler ayrılığını dayanak göstererek, normatif düzenlemelere yönelik değerlendirme yapılması, mevcut durumda, oldukça esnek ve geniş yorum tekniğinin kullanılmasını zorunlu kılmaktadır. Anayasa Mahkemesi bu problemi aşmak için neredeyse tüm yorum tekniklerini (ruhi [özsel]; gai [amaçsal]; sistematik, geniş̧letici vb.) kullanmak zorunda kalmaktadır (Çınar, 2018, s.266).

Anayasa Mahkemesinin yeni tarihli bir kararında getirdiği yorum ve ilkeye verdiği değer açıklıkla görülebilmektedir:

“...158. Hukuk devletinin en temel gereklerinden biri de hiç kuşkusuz kuvvetler ayrllĭg ilkesidir. Nitekim Anayasa'nın 7. maddesinde yasama yetkisinin Türk milleti adına Türkiye Büyük Millet Meclisine ait olduğu ve devredilemeyeceği; 8. maddesinde yürütme yetki ve 
görevinin Cumhurbaşkanı ve Bakanlar Kurulu tarafindan kullanılacağı; 9. maddesinde de yargı yetkisinin Türk Milleti adına bağımsız mahkemelerce ifa edileceği belirtilerek temel bir anayasal tercih olarak kuvvetler ayrıliğı ilkesinin benimsendiği açıkça ortaya konulmuştur. Anayasa'nın Başlangıç kısmının dördüncü paragrafinda ise 'Kuvvetler ayrımının, Devlet organları arasında üstünlük sıralaması anlamına gelmeyip, belli Devlet yetki ve görevlerinin kullanılmasından ibaret ve bununla sinırlı meden̂̂ bir iş bölümü ve iş birliği olduğu ve üstünlügün ancak Anayasa ve kanunlarda bulunduğu' belirtilerek bu ilkenin mahiyeti açıklanmıştır.” (Resmi Gazete, resmigazete.gov.tr/eskiler/2017/08/20170803-9.pdf).

Anayasa Mahkemesi konuyu ele alırken öncelikle Anayasa'da Kuvvetler Ayrıllı̆g ilkesine yer verildiğini dolambaçlı bir yoldan izah etmeye çalışmakta ve akabinde kararlarında kuvvetler ayrılığ ilkesini ölçüt olarak kullanmaktadır. Oysa, incelenen devletlerin ve birçok çağdaş demokratik anayasa sahip devletin anayasalarında hem yapılanma olarak hem de normatif temel değer olarak net ifadeler ile kuvvetler ayrılığı ilkesi, yer almaktadır. Kuvvetler ayrılığı ilkesinin önem ve değeri gereği, Türkiye Cumhuriyeti'nin devlet yapılanmasında ve Anayasal metninde yer alması gerektiğine kuşku yoktur. Tüm yargı kararlarının Anayasa Mahkemesinin emsal kararında olduğu gibi kuvvetler ayrılığı ilkesini kıstas almaları bir zorunluluktur. Öyleyse, yasama ve yürütme organlarının bu ilkeye uyumlu eylem ve işlem gerçekleştirebilmesi, bunun yanı sıra Anayasa Mahkemesinin ve hatta diğer mahkemelerin kararlarına dayanak ve kaynak teşkil edebilmesi açısından, kuvvetler ayrılığı ilkesine açıkça, kaplamı ve kapsamı belirtilerek anayasa metni içinde yer verilmesi gereklidir. Hatta devletin temel niteliği olduğu hususu vurgulanarak düzenleme yapılması yasama-yürütme-yarg1 organlarını bağlayıcı olabilmesi ve hukuk tekniği açısından doğru ve faydalı bir uygulama olacaktır.

\section{SONUÇ}

Kuvvetler ayrıllı̆ı ilkesinin asıl hedefi bir devlet organında kontrolsüz bir şekilde güç toplanmasının önüne geçmektir. Kuvvetler ayrılı̆̆ birçok şekilde gerçekleştirilebilir. Devlet fonksiyonları arasında hem yatay ve hem de dikey güç dağılımı bunun bir yöntemidir. Örneğin Yasama ve yürütme fonksiyonlarının yetki alanları kesin çizgilerle ayrıştıııldığında, yatay bir kuvvetler ayrılı̆̆ından söz edilebilirken; yürütmenin kendi içinde (bir nevi hiyerarşik) görev ve yetki bölüştürmesi yapılmak suretiyle, ya da çift meclis sistemi getirilerek yasama organı içinde dikey bir kuvvetler ayrılığ sağlanabilmektedir.

Dünya uygulamalarına bakıldığında, siyasi iktidar odaklarından herhangi birinde güç birikmesini önlemenin birçok yolu olduğu görülmektedir. Federatif devlet yapılanmalarında federal devletlere çeşitli yetkiler tanınarak; üniter devlet yapılanmalarında yerinden yönetim teşkilatlarının yönetsel özerklikleri genişletilerek, parlamentoda muhalefetin güçlü bir şekilde varlığının ve denetimsel etkinliğinin sağlanması suretiyle, yasama, yürütme ve yarg1 kuvvetlerinin temel hak ve özgürlüklere müdahale olanakları ortadan kaldırılarak, medyaya etkin olabileceği bir yaşam alanı sağlanarak, işçi ve işveren sendikalarına, sivil toplum örgütlerine, bilim kuruluşlarına ve üniversitelere özerk alanlar açarak, yasama, yürütme ve yargı organlarında denetimsiz güç birikmesinin önüne geçilebilir. Tüm bunlara ek olarak demokrasiyi esas alan, insan hak ve özgürlüklerini koruma amacı güden uluslararası kuruluşlara bağlayıcı uluslararası antlaşmalar ile dâhil olunması, bunların denetim mekanizmalarına, devlet uygulama ve örgütleri üzerinde inceleme yetkileri tanınması da devlet kuvvetlerinin kontrolsüz kullanımının önüne geçen diğer alternatifler olarak karşımıza çıkmaktadır.

Kuvvetler ayrılığı için anayasal demokrasi ve anayasal demokrasi için hukuk devleti mutualizm denen, biri olmadan diğerinin başarılı şekilde var olamayacağı, simbiyotik yaşam bütünlüğü içindedir. Hukuk devletinde, devlet yalnız kural koymaz, aynı zamanda bu kurallar ile kendisini bağlı kabul eder ve eylem ve işlemlerini bu çerçevede gerçekleştirir. Çağdaş, modern, güçlü devletler liginde en ön siralarda bulunan devletlerin, kuvvetler ayrıllğını ve demokratik sistemlerini istikrarla sürdüren devletler olduğunu gözlemlememiz kuvvetler ayrıllğının tüm kurum ve kurallarıyla hayata geçirilmesinin zorunluluğunu açıkça ortaya koymaktadır.

Yürütme ve yasama organının otokontrol ile kendiliğinden kendi sınırlarında kalması şeklinde ifade edebileceğimiz bu idealize edilmiş durum her zaman gerçekleşmeyebilir. Hem mevzuat düzenlemeleri 
yapan yasama organı hem de yasaları uygulamakla yetkili olan yürütme kuvveti insan hak ve özgürlüklerine, evrensel hukuk kaidelerine uygun olmayan eylem ve işlemler tesis edebilir. Yasama ve yürütmenin, hukuka aykırı ve haksız uygulamaları karşısında bireysel hak ve özgürlükleri koruyabilecek sığınma limanı olarak geriye sadece yargı kuvveti kalmaktadır. Bu nedenle kuvvetler ayrılığını gerçekleştirmek noktasında anayasa yargısının, genel yargının, yargı bağımsızlığının ve tarafsızlığının önemi son derece yüksektir. Anayasada "kuvvetler ayrımının-devlet organlarının yetki ve görevlerini kullanılmasından ibaret ve bununla sınırlı" olması şeklindeki tanımlamanın, çağdaş devlet düzenlemelerinde olduğu gibi kuvvetlere ayrı ayrı özerk alanlar tahsisi etmekten çok aslında belli bir bütünselliği ifade ettiği gözden kaçmamaktadır. Kuvvetle muhtemeldir ki devlet organ ve fonksiyonlarının uygulamada karşılaştıkları çatışmalı sıkıntıların temelinde bu felsefi yaklaşım yatmaktadır. Anayasa Mahkemesi başta olmak üzere, tüm yargı organlarının kararlarında "Kuvvetler Ayrılığı" ölçütünü kullanabilmeleri için anayasada daha net ve açık ifadelerle ve ayrıcalıklı üstün norm olarak kuvvetler ayrılığı ilkesinin düzenlenmesi gerektiği değerlendirilmektedir.

\section{KAYNAKÇA}

Acton, J. D. (1887). Demeçler. 5 Haziran 2019 tarihinde https://goo.gl/uuoeB6 adresinden erişildi.

Akın, İ. (1990). Kamu hukuku. İstanbul: Beta Yayınları.

Almanya Federal Cumhuriyeti Anayasast (Basic Law for the Federal Republic of Germany). 5 Haziran 2019 tarihinde https://www.btg-bestellservice.de/pdf/80201000.pdf adresinden erişildi.

Amerika Birleşik Devletleri Anayasast. 18 Nisan 2019 tarihinde https://www.archives.gov/foundingdocs/constitution-transcript adresinden erişildi.

Amerika Birleşik Devletleri Yüce Mahkemesi (Supreme Court of the US). 18 Mart 2019 tarihinde https://www.supremecourt.gov/orders/scannedjournals.aspx adresinden erişildi.

Anayasa Ortak Komitesi (Joint Committe on Draft Civil Contingencies Bill). 9 Mayıs 2019 tarihinde https://publications.parliament.uk/pa/jt200203/jtselect/jtdcc/184/18407.htm adresinden erişildi.

Aslan, R. (2010). Kuvvetler ayrllı̆̆ teorisi ve uygulamalı örnekleri (Ingiltere, Almanya, ABD ve İsviçre). Bursa: Dora Yayıncılık.

Aristoteles (1975). Politika. (Çev. Mete Tuncay). İstanbul: Remzi Yayınevi.

Bilgin, M. (2015). Parlamenter sistemin doğduğu ülke: Ingiltere, karşılaştırmalı hükûmet sistemleri (parlamenter sistem). Ankara: TBMM Yayınları.

Çınar, M.F. (2017). Türkiye'nin anayasal demokrasi yolu ve kuvvetler ayrıllı̆g ilkesinin serencamı, Akademik Bakış Dergisi, 64, 586-607.

Çınar, M.F. (2018). Hükümet sistemlerinin tarihsel gelişimleri ışı̆̆ında Türkiye içıin anayasal önermeler. Yayınlanmamış doktora tezi, Dokuz Eylül Üniversitesi, İzmir.

Çubukçu, H. (2015). Kuvvetler ayrıllğı prensibinin Türkiye'de uygulanış biçimi (son ụ̧̈ yıllık uygulama). Yayınlanmamış yüksek lisans tezi, İstanbul Gelişim Üniversitesi Sosyal Bilimler Enstitüsü, İstanbul.

Doehrıng, K. (2002). Genel devlet kuramı-genel kamu hukuku. (Çev. Ahmet Mumcu). 4.Baskı. İstanbul: İnkılap Yayınevi.

Eroğul, C. (2016). Çağdaş devlet düzenleri. 10. Basım. Ankara: İmaj Yayınevi.

Fransa Cumhuriyetinin Politik Tarihi. 15 Mart 2019 tarihinde http://www.france-politique.fr adresinden erişildi.

Göze, A. (1993). Siyasal düşünceler ve yönetimler. 6.Baskı. İstanbul: Beta Yayınlar1.

Gözler, K. (2018). Anayasa hukukunun genel esasları. 10.Baskı. Bursa: Ekim Basım Yayın Dağıtım. 
Hobbes, T. (2007). Leviathan veya bir din ve dünya devletinin içeriği, biçimi ve kudreti. (Çev. Semih Lim). 6.Bask1. İstanbul: Yapı Kredi Yayınları.

Insan ve Yurttaş Haklart Bildirgesi. 18 Mart 2019 tarihinde http://avalon.law.yale.edu/18th century/rightsof.asp adresinden erişildi.

Locke, J. (2002). Sivil toplumda, devlet, uygar yönetim üzerine ikinci inceleme. (Çev. Serdar Taşç1, Hale Akman). İstanbul: Metropol Yayınları.

Montesquieu (1963). De L'Esprit des Lois (Kanunların ruhu üzerine). I. Cilt. (Çev. Fehmi Baldaş). Ankara: M.E.B. Basımevi.

Oder, B. E. (2004). Avrupa Birliği’nde anayasa ve anayasacılık. İstanbul: Anahtar Kitaplar Yayınevi.

Özçelik, S. (1984). Anayasa hukuku. İstanbul: Beta Yayınları.

Resmi Gazete (03.08.2017). Anayasa Mahkemesinin, 04.05.2017 tarih ve 2015/41-2017/98 say1l karar1. 21 Mart 2019 tarihinde http://www.resmigazete.gov.tr/eskiler/2017/08/20170803-9.pdf adresinden erişilid.

Rusya Federasyonu Anayasast (Constitution of Russian Federation). 22 Mart 2019 tarihinde http://www.ksrf.ru/en/Info/LegalBases/ConstitutionRF/Pages/default.aspx adresinden erişildi.

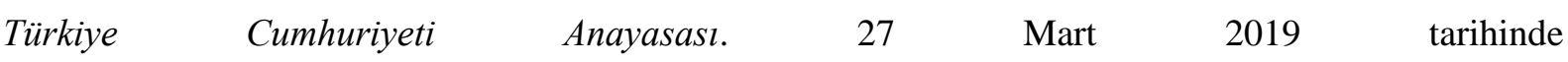
https://www.anayasa.gov.tr/tr/mevzuat/anayasa adresinden erişildi.

Wheare, K. C. (1985). Modern anayasalar. Ankara: Değişim Yayınları. 